\title{
Author Correction: A community-based transcriptomics classification and nomenclature of neocortical cell types
}

Rafael Yuste Dichael Hawrylycz DD, Nadia Aalling D , Argel Aguilar-Valles, Detlev Arendt, Ruben Armañanzas (D), Giorgio A. Ascoli, Concha Bielza, Vahid Bokharaie, Tobias Borgtoft Bergmann D, Irina Bystron, Marco Capogna $\mathbb{D}$, YoonJeung Chang, Ann Clemens (D, Christiaan P. J. de Kock, Javier DeFelipe, Sandra Esmeralda Dos Santos, Keagan Dunville, Dirk Feldmeyer, Richárd Fiáth, Gordon James Fishell, Angelica Foggetti, Xuefan Gao, Parviz Ghaderi D,

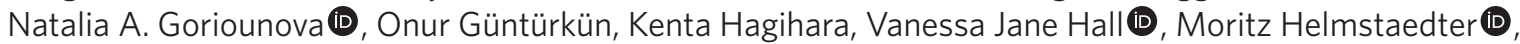
Suzana Herculano-Houzel, Markus M. Hilscher (D), Hajime Hirase, Jens Hjerling-Leffler (D), Rebecca Hodge (D), Josh Huang (D), Rafiq Huda Donstantin Khodosevich, Ole Kiehn D Denner Koch, Eric S. Kuebler (D), Malte Kühnemund, Pedro Larrañaga, Boudewijn Lelieveldt, Emma Louise Louth, Jan H. Lui, Huibert D. Mansvelder (D, Oscar Marin (D), Julio Martinez-Trujillo Domeira Moradi Chameh, Alok Nath Mohapatra Dermany Munguba, Maiken Nedergaard (D), Pavel Němec, Netanel Ofer (D), Ulrich Gottfried Pfisterer, Samuel Pontes D, William Redmond (D), Jean Rossier, Joshua R. Sanes Dichard H. Scheuermann Did, Esther Serrano-Saiz, Jochen F. Staiger, Peter Somogyi, Gábor Tamás $\mathbb{D}$, Andreas Savas Tolias (D), Maria Antonietta Tosches Di Miguel Turrero García, Christian Wozny D, Thomas V. Wuttke D, Yong Liu (D), Juan Yuan, Hongkui Zeng (D) and Ed Lein (D)

Correction to: Nature Neuroscience https://doi.org/10.1038/s41593-020-0685-8, published online 24 August 2020.

In the version of this article initially published, multiple errors appeared in the author and affiliations lists. The errors have been corrected in the PDF and HTML versions of this article.

\begin{abstract}
(C) Open Access This article is licensed under a Creative Commons Attribution 4.0 International License, which permits use, sharing, adaptation, distribution and reproduction in any medium or format, as long as you give appropriate credit to the original author(s) and the source, provide a link to the Creative Commons license, and indicate if changes were made. The images or other third party material in this article are included in the article's Creative Commons license, unless indicated otherwise in a credit line to the material. If material is not included in the article's Creative Commcons license and your intended use is not permitted by statutory regulation or exceeds the permitted use, you will need to obtain permission directly from the copyright holder. To view a copy of this license, visit http://creativecommons.org/licenses/ by/4.0\%.
\end{abstract}

Published online: 19 March 2021

https://doi.org/10.1038/s41593-020-00779-0

(C) The Author(s) 2021

\section{Publisher Correction: Transcriptome-scale spatial gene expression in the human dorsolateral prefrontal cortex}

Kristen R. Maynard D, Leonardo Collado-Torres D, Lukas M. Weber, Cedric Uytingco, Brianna K. Barry (D), Stephen R. Williams, Joseph L. Catallini II, Matthew N. TranD , Zachary Besich, Madhavi Tippani, Jennifer Chew, Yifeng Yin, Joel E. Kleinman, Thomas M. Hyde Did, Nikhil Rao, Stephanie C. Hicks (D), Keri Martinowich D and Andrew E. Jaffe (D)

Correction to: Nature Neuroscience https://doi.org/10.1038/s41593-020-00787-0, published online 8 February 2021.

In the version of this article initially published, in the "Additional information" section, the peer review information erroneously stated that peer review reports were available. They are not available for this article.

The error has been corrected in the PDF and HTML versions of this article.

Published online: 18 February 2021

https://doi.org/10.1038/s41593-021-00817-5

(c) The Author(s), under exclusive licence to Springer Nature America, Inc. 2021 